\title{
Teachers' Perceptions and Attitudes towards the Science, Technology and Society Approach in Science Teaching
}

\author{
Wan Nurul Izzati W. Kamizi, Zanaton H. Iksan* \\ Faculty of Education, Universiti Kebangsaan Malaysia, Bangi, Malaysia \\ Email: *zanaton.iksan@ukm.edu.my
}

How to cite this paper: Kamizi, W. N. I. W., \& Iksan, Z. H. (2021). Teachers' Perceptions and Attitudes towards the Science, Technology and Society Approach in Science Teaching. Creative Education, 12, 22162227.

https://doi.org/10.4236/ce.2021.129169

Received: August 26, 2021

Accepted: September 25, 2021

Published: September 28, 2021

Copyright $\odot 2021$ by author(s) and Scientific Research Publishing Inc. This work is licensed under the Creative Commons Attribution International License (CC BY 4.0).

http://creativecommons.org/licenses/by/4.0/

\begin{abstract}
The industrial revolution 4.0 has a positive impact on the world of education, especially from the aspect of teacher's pedagogy. The Science, Technology and Society (STS) approach is a more meaningful approach by involving students in solving daily life problems that is closely related to the concept of Science. The purpose of the study was to identify the perceptions and attitudes towards Science, Technology and Society (STS) approaches among science teachers. This study used survey method and a questionnaire as an instrument. It includes two parts, teachers' perceptions and attitudes towards STS approach in teaching Science with the Cronbach alpha reliability value of perception was $\alpha=0.925$ and attitude was $\alpha=0.920$. The study was conducted on 80 Science teachers respondents were selected using cluster and simple random sampling. The findings showed that teachers' perceptions of 1) science and technology $($ mean $=4.33, \mathrm{sd}=0.441), 2)$ science and community $($ mean $=$ 4.06 , sd $=0.343), 3)$ technology and community (mean $=4.26$, $\mathrm{sd}=0.443), 4)$ the role of teachers (mean $=4.15, \mathrm{sd}=0.384$ ) and teachers' attitudes towards STS approach (mean $=4.20$, sd $=0.367$ ) were at a high level. The results of the inferential analysis showed that there were significant differences based on gender for the teachers' perceptions for technology and community. There was also a strong positive relationship between perceptions and teachers' attitudes towards the STS approach in Science teaching. The results of this study showed that the teachers had a positive perception and attitude towards the science teaching based on the use of technology and real problems. Teachers also agree that science teaching was more meaningful by using real-life examples that happened in everyday life. The implication of this study is to increase the number of courses and partnership activities among teachers to enable them to exchange opinions on the best methods of teaching science for students in accordance with online learning.
\end{abstract}




\section{Keywords}

Science, Technology and Society (STS), Constructivism Theory, Teachers'

Perception, Teachers' Attitude

\section{Introduction}

Science Technology and Society (STS) is an integration of three fields, namely Science, Technology and Society. The field of science emphasized the theories and concepts of science and technology which include the technology produced as well as the skills to use such technologies to solve problems. The components of community include the scientific phenomena that occurred in life and the ability to use scientific, technological and thinking skills to make wise decisions in community life situations (Sulaiman, 2000). The STS approach provides an opportunity to train students' thinking skills, problem solving, and decision making (Primatuti \& Atun, 2018).

Improvements can be seen in student achievement for science subjects after the STS intervention was carried out (Hafizah, 2017; Tarntip \& Chockhai, 2014; Kartikasari, Roemintoyo, \& Yamtinah, 2018). Most of the previous studies have only focused on teachers' perceptions of STS approach and the impact of this approach on student achievement involving foreign countries but less research on teacher perception and effectiveness of STS approach in Malaysia although this approach had long been embodied in science curriculum standards. Hands on activities and fieldwork are the basis of STEM learning that can affect students in applying existing knowledge and learning that gives meaning to the students (Abdullah, 2015).

As STS is the first approach in teaching science subjects, nowadays those elements had been improvised in STEM (Science, Technology, Engineering, and Mathematics) and in STEAM (Science, Technology, and Mathematics). But for this research is only focus on the elements of Science, Technology and how the Engineering parts take place in a useful knowledge which can also relate with the society elements. Society in this research is about the integration of science and technology that can help students to understand more for science concept.

A teacher's teaching experience influences their techniques and the way they present the knowledge (Syed Ali et al. 2018). The senior teachers usually have high self-efficacy in their pedagogy during the learning and teaching process (Syed Ali et al. 2018). Teachers' perceptions and attitudes have an important impact on the STS approach in line with the demands of STEM in PPPM (2013-2025). One of the elements for knowledge in DSKP 2020 is the maintenance and continuity in life which has a connection with this research whereby the techniques in teaching science is to let students explore the science elements in their daily life, which can help them to have interest in this subject (Dokumen Standard KurikulumPrestasi, 2020). Therefore, this study will identify teachers' perceptions 
and attitudes towards Science, Technology and Society (STS) approaches, in simpler words, to what extent the teachers think of the relationship between Science, Technology and Society. In this regard, knowing the perceptions and attitudes of teachers can provide an opportunity for curriculum development and improving the approach used for teaching Science. It is hoped that the findings will provide useful information to certain parties in introducing reforms in the education system.

As the STS is still relevant in STEM approach, teachers need to be the master of content of this approach. To enable students, relate the science with their daily life activity, providing in-depth problem solving through STS approach with authentic experiences requires that teachers are skilled with this unique student-directed pedagogy. Educators must understand the value and power of concept STS to enable students to fail and persevere. Thus, this study will investigate more detail about teacher's perception and attitude towards STS in their pedagogy teaching science in school. The latest study was only focusing on the implication and teacher perception in STEM but for this research only more focus on Science, Technology, and the Society in science subject.

Overall, this study will discuss teachers' perceptions and attitudes towards STS approaches in teaching Science. The study also discusses the differences in teachers' perceptions and attitudes towards STS approaches based on gender and teaching experience and the relationship between teachers' perceptions and attitudes towards STS approaches in science teaching.

\section{Perception on Science and Technology to the Society}

Teachers' perceptions towards science and technology are very complex, which are divided into two views, first the teachers who are more inclined to the constructivists approach and secondly the teachers who are more inclined to the traditional thinking (Mansour, 2010). The importance of science and technology plays an important role to the society as it make life easier and help students to better understand what happens in life through the concept of science (Ersay, 2015). There are still students who only understand the concept of science on the surface and have a limited understanding to make connections between the use of science and technology and its application to the community (Fakhriyah et al., 2017).

For the students' perceptions of the STS approach, there are several studies show that this approach can have a positive impact on student achievement and strengthening the understanding of scientific concepts. STS teaching approach shows a better improvement in students' cognitive level compared to students who follow learning in the traditional method (Primastuti \& Atun, 2018). In addition, this STS approach can also provide an opportunity for teachers to train students to improve their thinking skills as well as developing problem solving and decision-making skills. Students who use the STS approach show improvement in terms of academic achievement after being taught using textbooks based on science, technology and issues that occur in daily human life. For teachers' 
perspectives on the STS approach, the teachers strive to develop their students' ability to understand what is going on around them.

By using the STS approach, teachers and students making judgments of various views, doing collaborative research and problem solving. All this encourages a constructivist environment for learning and teaching involving students' life experiences. There are many advantages for students in situations where they will share information collaboratively, present their perspectives on the issues being studied and reach group solutions on the issues. The implications of this process affect both the teaching and learning of science by students. It can also increase students' confidence to solve personal, local, and daily lives problems involving scientific concepts (Kapici et al., 2017).

The previous studies also show that the STS approach can improve students' skills to solve questions that require higher order thinking skills (Kartikasari, Roemintoyo, \& Yamtinah, 2018). This finding is also supported by the study of Tarntip and Chockchai (2014) that changes in textbook make learning more fun to the students and at the same time increase their level of understanding. The use of textbooks that have an STS curriculum makes teachers more creative in teaching than traditional methods. In addition, students are able to investigate the problems that occur around them using their own understanding. These increase the positive attitude of students towards science and improve their relationship with the teachers.

Teachers are an example of persons who play the role of catalyst in the talent development process (Gagne', 2007). In this role, teacher can either help or hinder a student's development in science subject. Thus, the relationship between the concept of science to the field of technology and community needs to be considered due to the rapid development of the current world of education leading to the Industrial Revolution 4.0. When a country is advanced in science and technology, this indirectly improves the country's economy because there is no need to depend on other countries to compete and get supplies (Ersay, 2015). Therefore, educators need to review the effective techniques and methods to increase the percentage of students who take science streams as well as restore students' interest in science subjects to attain the national targets to be a developed country and to produce competitive students with skills that are needed for this 21 st century.

\section{Methodology}

This study used survey design. The respondents of the study consisted of male and female secondary school science teachers. A total of 80 science teachers with teaching experience ranging from 5 - 11 years and above were selected as respondents. Cluster random sampling techniques were selected to determine the school selection process and simple random sampling for respondent selection.

\section{Instruments}

This study used questionnaires as the research instrument. The questionnaire 
instrument for this study was adapted from a study by Mansour (2010) and instrument by Aikenhead, Ryan and Fleming (1989) on the Views of ScienceTechnology-Society (VOSTS). The questionnaire was divided into three parts, namely Part A, Part B and Part C. Part A contained the demographic characteristics of the respondents while Part $B$ contained 21 items of questionnaires related to teachers' perception. Meanwhile part C contains 10 items related to teachers' attitudes towards the STS approach. Questionnaire was distributed to the relevant schools and collected in stages. Respondents were given the opportunity to answer the questionnaires according to the suitability of their time.

The data obtained were analyzed using descriptive tests (percentage, mean and standard deviation). The scores for the questionnaire items used a Likert scale from 1 (Strongly Disagree) to 5 (Strongly Agree).

For the reliability of the instrument, the analysis of Cronbach's Alpha was used for each variable that had been developed. Table 1 showed the reliability that the instrument had high validity and reliability and could produce more accurate data.

\section{Findings and Discussion}

\subsection{Perceptions and Attitudes towards STS Based on Gender and Teaching Experiences}

This research measures the perceptions and attitudes towards Science, Technology and Society Approaches based on Gender and teaching experience. Table 2 shows the perceptions and attitudes towards Science, Technology and Society Approaches based on Gender.

Based on Table 3, most of the constructs do not differ between gender except for there is gender difference related to the perceptions of technology and society. Male teachers have an opinion that technology had a huge impact in society, such as made the life easier compared to female teachers. Other constructs did not show any differences in gender such as the constructs of perception of science and technology, science and society, constructivist perceptions and attitudes of teachers towards science, technology and society approaches in science teaching.

Teaching experience also contribute with the perception and attitudes towards science, Technology and society. Table 3 showed on this issue.

Table 3 showed the differences in teachers' perceptions and attitudes towards science, technology and society approaches based on the teaching experience. Teachers' years of experience are inconsistently related to their perception of STEM integration or approach and the teacher's value or interest in science and

Table 1. The Cronbach's alpha value of the study variables.

\begin{tabular}{ccc}
\hline Variable & No of items & Alpha Cronbach Value \\
\hline Perception & 20 & 0.925 \\
Attitude & 10 & 0.950 \\
\hline
\end{tabular}


Table 2. Perceptions and attitudes towards science, technology and society approaches based on gender.

\begin{tabular}{|c|c|c|c|c|}
\hline Construct & Gender & Mean Rank (MR) & $\mathbf{Z}$ & Sig \\
\hline Science and Technology & $\begin{array}{c}\text { Male } \\
\text { Female }\end{array}$ & $\begin{array}{l}45.77 \\
36.99\end{array}$ & -1.70 & 0.091 \\
\hline Science and Society & $\begin{array}{c}\text { Male } \\
\text { Female }\end{array}$ & $\begin{array}{l}45.91 \\
36.90\end{array}$ & -1.75 & 0.080 \\
\hline Technology and Society & $\begin{array}{c}\text { Male } \\
\text { Female }\end{array}$ & $\begin{array}{l}43.77 \\
38.32\end{array}$ & -1.042 & 0.030 \\
\hline Constructivist Perception & $\begin{array}{c}\text { Male } \\
\text { Female }\end{array}$ & $\begin{array}{l}37.94 \\
42.21\end{array}$ & -0.928 & 0.354 \\
\hline Attitude & $\begin{array}{c}\text { Male } \\
\text { Female }\end{array}$ & $\begin{array}{l}39.92 \\
40.89\end{array}$ & -0.185 & 0.853 \\
\hline
\end{tabular}

${ }^{* *}$ significant at $p<0.05$.

Table 3. Perceptions and attitudes towards science, technology and society approaches based on the teaching experience.

\begin{tabular}{|c|c|c|c|c|}
\hline Construct & Teaching Experience (Year) & Mean Rank (MR) & Chi Square & Sig \\
\hline & $1-5$ & 45.00 & & \\
\hline \multirow[t]{3}{*}{ Science and Technology } & $6-10$ & 42.71 & 0.364 & 0.834 \\
\hline & 11 and above & 39.71 & & \\
\hline & $1-5$ & 36.50 & & \\
\hline \multirow[t]{3}{*}{ Science and Society } & $6-10$ & 49.43 & 2.70 & 0.260 \\
\hline & 11 and above & 38.74 & & \\
\hline & $1-5$ & 11.00 & & \\
\hline \multirow[t]{3}{*}{ Technology and Society } & $6-10$ & 52.68 & 10.70 & 0.005 \\
\hline & 11 and above & 39.65 & & \\
\hline & $1-5$ & 33.50 & & \\
\hline \multirow[t]{3}{*}{ Constructivist Perception } & $6-10$ & 38.96 & 0.66 & 0.72 \\
\hline & 11 and above & 41.30 & & \\
\hline & $1-5$ & 27.50 & & \\
\hline \multirow[t]{2}{*}{ Attitude } & $6-10$ & 51.32 & 4.772 & 0.092 \\
\hline & 11 and above & 38.90 & & \\
\hline
\end{tabular}

society may mediate the relationship. For example, teacher's years of experience seem to have some influence on his/her feelings. According to the table, only the constructs of perception of technology and society showed significant differences based on the teaching experience. Teachers with 6 - 10 years of teaching experience gave a positive perception of technology and society. The other constructs did not show significant differences in the approaches of science, technology, and society in terms of perceptions or attitudes of teachers. A research study had shown that more experienced teachers ( $>15$ years) had more positive view of importance of STEM education when compared with the new teachers (between 1- and 5-years' experience) (Park et al., 2016). The construct that showed the highest significant value was the perception of science and technology. Teachers 
with teaching experience 11 years and above did not think that science and technology were closely related to each other.

\subsection{Relationship between Perceptions and Attitudes towards STS in Science Teaching}

Ho5: There is no relationship between teachers' perceptions of science, technology and society approaches and teachers' attitudes.

Table 4 shows the result of the relationship between perceptions and attitudes towards STS approaches in Science teaching.

The Spearman Correlation Coefficient Test was conducted to test the relationship between teachers' perceptions of Science, Technology and Society (STS) approach and teachers' attitudes towards Science, Technology and Society (STS) approach. The study found that there was a significant positive correlation between teachers' perceptions of the STS approach and teachers' attitudes towards the STS approach in Science teaching with the correlation values ( $\mathrm{rs}(2)=0.765$, $p=0.00<0.05$ ). These findings indicated that there was a strong relationship between teachers' perceptions of Science, Technology and Society approaches and teachers' attitudes towards STS approaches in teaching Science. In conclusion, the null hypothesis was rejected and this showed that there was a significant relationship on teachers' perceptions and attitudes towards science, technology and community approaches in science teaching based on teaching experience. Ultimately, teachers' attitudes towards science, technology and society (STS) approaches in science teaching depended on teachers' perceptions of things.

Teachers' perceptions had been supported by several studies which showed that it influenced teachers' attitudes in situations involving teaching and learning methods (Sam et al., 2015). If teachers have a positive perception of the teaching methods and reforms carried out, then they will also be motivated to support those methods and applied them in their teaching without demand by the superiors. Yet there are several past studies that proved that teachers' perceptions are different from the gender aspect. A study by (Titok, 2018) proved that there are differences in perceptions between male and female teachers for teaching methods using teaching aids (BBM). The study fully supports the findings of this study that there are differences in teachers' perceptions of Technology and Society based on gender. Male teachers are more positive about the development of technology that benefits students and their daily lives than female teachers.

Table 4. Spearman Rho correlation coefficient analysis for relationship between perception and attitude towards STS.

\begin{tabular}{cccccc}
\hline & N & Mean & $\begin{array}{c}\text { Standard } \\
\text { Deviation }\end{array}$ & $\begin{array}{c}\text { Spearman Correlation } \\
\text { Coefficient, } \mathbf{r}\end{array}$ & $\begin{array}{c}\text { Asymp Sig. } \\
(2-\text { tail })\end{array}$ \\
\hline Perception & 80 & 4.20 & 0.333 & 0.765 & $0.00^{*}$ \\
Attitude & 80 & 4.20 & 0.367 & & \\
\hline
\end{tabular}

*Significant values at $p<0.05$. 
However, the results of the study as a whole did not show differences in teachers' perceptions of the Science, Technology and Society (STS) approach based on gender. This study is in line with several other studies such as (Sivakumar, 2018) which showed that perceptions between male and female teachers were the same for the teaching method as a professional teacher. Male and female teachers have the same perception of science and technology, science and society as well as from the aspect of teachers' role. This is because they are from the same field that is the field of science and the way of thinking is inclined towards the thinking of a scientist. This data is supported by Jamil and Ishak (2015) which also showed no difference between the gender of teachers on the productive pedagogical practices such as questioning techniques, discussion, linking content to students' experiences and real world as well as the application of noble values in teaching and learning. These two studies are closely related to the findings of this study because both involved pedagogy in teaching.

In this study, the attitudes towards the use of technology in teaching vary based on gender. The findings are supported by a study by Titok (2018), which shows that female teachers use technology more often in their teaching than male teachers. Learning in the era of the Industrial Revolution 4.0 required the teachers of to master the technological skills in their teaching. This situation of gender differences should not happen because all teachers should have the same understanding and mastery of the use of technology such as learning applications like "Kahoot", "Quizizz", "Padlet" and some other applications that can help make learning more interesting. Teachers are also encouraged to have skills in creating and operating their own blogs so that students can access them as additional information. As a teacher, they also need to always think of methods or ways to make science learning more meaningful.

For the aspect of teaching experience, the findings showed that teachers' perceptions of Technology and society are different from the aspect of teachers' teaching experience. Teachers with 6 - 10 years of teaching experience showed a positive perception of the relationship between technology and its importance to the community. Teaching experience had an impact on the extent to which teachers are exposed to the teaching methods and the extent to which they apply the pedagogy in the classroom.

Teachers' attitude can be defined as a positive or negative response or feeling of an individual to an object, situation, institution or person (Aikenhead, 2000). The formation of a positive attitude among teachers is very helpful in creating an effective personal learning environment for students (Ab Khalid et al., 2015). Teachers' attitudes towards change can be adjusted by providing more courses and trainings. The findings of this study support several other findings that there is no difference in attitudes between teachers based on teaching experience on science teaching using Science, Technology and Society approaches. Whether science teachers are still novices or experienced, all groups of teaching experience did not show any difference in the attitudes towards Science, Technology 
and Society approaches in Science teaching. This means that the majority of teachers in the science field have a positive attitude towards science teaching using real examples and making connections in the field of STEM, regardless of the teaching experience. The findings can also give the impression that science teachers get the same and adequate training while they are still at the trainee teacher level.

The perceptions about the STS approach showed that science teachers in Malaysia are up to date with the developments in the world of science education today. As STS is relevant to the STEM approach, hands-on activities and fieldwork can be the basis of STEM learning that can encourage students to apply it to the existing knowledge (Han et al., 2015). Based on the overall findings of the study, the researcher can conclude that teachers' perceptions and attitudes towards the STS approach are at the same level. All respondents had the same willingness to make improvements in teaching, increase their use of technology in teaching in order to give a clearer picture of the concept of science, and the willingness to join professional development courses for improvement in the education system. Through this study, it shows that teachers have enthusiasm and always strive to improve their teaching.

\section{Conclusion}

In a connection with new teaching platform nowadays, teacher needs to be the master content of the skill in using technology in their classroom. Online learning needs teacher to learn new software and application to enable students get the science concept in their own experience. As for the society concept, teachers have to relate student's daily life activity. Based on the entire study, researchers have succeeded in providing a clear picture of teachers' perceptions of science, technology, and society (STM) approaches in science teaching. In addition, this study can also prove that most teachers in Hulu Langat district have a positive attitude to make improvements in their teaching. This study also shows that there are no differences for teachers' perceptions of science and technology, science, and society as well as constructivist perceptions of the role of teachers. However, there are some differences in teachers' perceptions of technology and society based on the gender of teachers.

Male teachers showed a high perception of the use of technology in the teaching and learning of science more easily using real examples and phenomena. In addition, there is a positive relationship that exists between the two variables studied in this study, namely teachers' perceptions and attitudes towards the STM approach in the teaching of science. However, the method of data acquisition has limited some things in this study. There are some schools that do not cooperate fully with the researchers. In addition, the selection of the school sample was also slightly limited for the selected districts. Therefore, some suggestions for further research are presented to get a clearer and deeper picture of the extent of the application of teachers' teaching using Science, Technology and So- 
ciety (STM) approach in their teaching. Therefore, these further studies are expected to further strengthen the findings of existing studies as well as provide the real situation in the world of education today, especially in the science curriculum.

As for next research, researcher suggested that to take into account also teacher from mathematics and technology as these two fields are the most important areas in the STEM curriculum. Thus, by taking into account the perspective of teachers in the field of technology and mathematics can further strengthen the importance of science teaching involving the use of technology and phenomena that occur in daily life. Lastly, this study can be further improved if carried out with construction of modules that use the approach of Science, Technology and Society as used by researchers in several universities at the international level. Through the use of modules, the effectiveness of this approach can measure more accurately.

As an agent of student success, teachers need to master various skills such as understanding the approach implemented during teaching. In addition, teachers' attitudes influence their acceptance of the innovations carried out. If teachers always have a positive and open-minded attitude towards changes, then the teaching approach would also be in line with the development of the current world of education. Teacher support is very important to the innovations made in the context of learning and teaching.

\section{Acknowledgements}

This research was partially supported by Faculty of Education, Universiti Kebangsaan Malaysia Fund under the Dana GG-2021-001.

\section{Conflicts of Interest}

The authors declare no conflicts of interest regarding the publication of this paper.

\section{References}

Ab Khalid, R, Ahmad, J. \& Hamdan, A. (2015). Pembentukan Sikap Positif Guru Terhadap Pelaksanaan Aktiviti Pentaksiran (The Development of Teacher's Positive Attitude towards the Implementation of Assessment Activities). Journal of Personalized Learning, 1, 77-84.

Abdullah, A. H. (2015). KBAT: Tugas Guru SemakinMencabar. Dewan Masyarakat, 39-41.

Aikenhead, G. S. (2000). Renegotiating the Culture of School Science. In R. Millar, J. Leach, \& J. Osborne (Eds.), Improving Science Education (pp. 245-264). Open University Press.

Aikenhead, G. S., Ryan, A. G., \& Fleming, R. W. (1989). Views on Science Technology Society. University of Sackatchewan.

Dokumen Standard KurikulumPrestasi. (2020). BiologiTingkatan 4 KSSM. Kementerian Pendidikan Malaysia.

Ersay, E. (2015). Investigating Pre-Service Earl Childhood Teachers' Views on Science 
Technology and Society Issues in Turkey. Procedia-Social and Behavioral Sciences, 191, 1397-1402. https://doi.org/10.1016/j.sbspro.2015.04.318

Fakhriyah, F., Masfuah, S., Roysa, M., Rusilowati, A., \& Rahayu, E. S. (2017). Students'Science Literacy in the Aspectt of Content Science. Jurnal Pendidikan IPA Indonesia, 6, 81-87. https://doi.org/10.15294/jpii.v6i1.7245

Gagne', F. (2007). Ten Commandments for Academic Talent Development. The Gifted Child Quarterly, 51, 93-118. https://doi.org/10.1177\%2F0016986206296660

Hafizah, A. (2017). Pelaksanaan Pengajarandan Pembelajaran Koperatif Berasaskan Abad ke 21: Satu Tinjauandi SekolahMenengahKebangsaan Pekan Nanas. Universiti Tun Hussien Onn Malaysia.

Han, S., Yalvac, B., Capraro, M. M, \& Capraro, R. M. (2015). In-Service Teachers' Implementation and Understanding of STEM Project Based Learning. Eurasia Journal of Mathematics, Science \& Technology Education, 11, 63-76. https://doi.org/10.12973/eurasia.2015.1306a

Jamil, H. \& Ishak, N. A. (2015). Pre-University Form Six Teachers' Pedagogical Practices in Enhancing Students' Intellectual Quality in Malaysian Secondary School. Australian Journal of Basic and Applied Science, 8, 33-40.

Kapici, H. O., Akcay, H., \& Yager, R. E. (2017). Compariosn of Science-Technology-Society Approach and Textbook Oriented Instruction on Students' Abilities to Apply Science Concepts. International Journal of Progressive Education, 13, 18-28.

Kartikasari, A., Roemintoyo, \& Yamtinah, S. (2018). The Effectiveness of Science Textbook Based on Science Technology Society for Elementary School Level. International Journal of Evaluation and Research in Education (IJERE), 7, 127-131. http://doi.org/10.11591/ijere.v7i2.13022

Mansour, N. (2010). Science Teachers' Perspective on Science-Technology-Society (STS) in Science Education. Eurasian Journal of Physics and Chemistry Education, 2, 123-157. https://doi.org/10.51724/ijpce.v2i2.187

Park, H., Byun, S., Sim, J., Han, H., \& Baek, Y. S. (2016). Teacher's Perceptions and Practices of STEAM Education in South Korea. Eurasia Journal of Mathematics, Science \& Technology Education, 12, 1739-1553. https://doi.org/10.12973/eurasia.2016.1531a https://www.ejmste.com/download/teachers-perceptions-and-practices-of-steam-educa tion-in-south-korea-4573.pdf

Primastuti, M., \& Atun, S. (2018). Science Technology Society (STS) Learning Approach: An Effort to Improve Students' Learning Outcomes. Journal of Physics Conference Series, 1097, Article ID: 012062. https://doi.org/10.1088/1742-6596/1097/1/012062

Sam, K.-L., Ho, F.-C., \& Lam, S.-C. (2015). Perception of Teachers towards Inclusive Education (PTIE): An Investigation on Scale Construct and Item CalibrationPerception of Teachers towards Inclusive Education (PTIE): An Investigation on Scale Construct and Item Calibration. International Journal of Culture and History (EJournal), 1, 54-62. https://doi.org/10.18178/ijch.2015.1.1.010

Sivakumar, R. (2018). Teachers Attitude towards Teaching Profession in Relation to Their Self-Concept. Journal of Contemporary Educational Research and Innovations, 8, 283288.

Sulaiman, S. (2000). Pendidikan Sains, Teknologi Dan Masyarakat. Jurnal Pendidikan Universiti Teknologi Malaysia, 6, 66-76.

Syed Ali, S. K., Abdul Rauf, P., \& Salimin, N. (2018). Hubungan Antara Pengalaman Mengajar dan Perancangan Pengajaran Dalam Kalangan Guru Pendidikan Jasmani Tingkatan 4 [Relationship between Teaching Experience and Teaching Planning among Teachers 
of Form 4's Physical Education]. International Journal of Education, Psuchology and Counseling, 2, 268-277.

Tarntip, C., \& Chockchai, Y. (2014). The Outcomes of Teaching and Learning about Sound Based on Science Technology and Society (STS) Approach. Procedia-Social and Behavioral Sciences, 116, 2286-2292. https://doi.org/10.1016/j.sbspro.2014.01.561

Titok, J. (2018). Sikap dan Jantina Guru Bahasa Melayu Sekolah Rendah Daerah Serian Terhadap Pemilihan Bahan Bantu Mengajar (The Attitude and Gender of Malay Language Primary School at Serian District towards the Choosing of Teaching Aids). Jurnal Pendidikan Bahasa Melayu; JPBM (Malay Language Education Journal-MyLEJ, 8, 13-21. 